\title{
JENIS VARIABEL DAN SKALA PENGUKURAN, PERBEDAAN STATISTIK DESKRIPTIF DAN INFERENSIAL
}

\author{
DAN STATISTIK PARAMETRIK DAN NONPARAMETRIK
}

\author{
MUHAMMAD DAHRI \\ 18210035 \\ Dahrii.kk@gmail.com
}

\begin{abstract}
ABSTRAK
Artikel ini bertujuan untuk menyarankan mahasiswa untuk mengenal jenis- jenis variable, skala pengukuran, mengetahui Perbedaan statistik deskriptif dan inferensial, dan memahami Statistik Parametrik dan nonparametric. Hal ini penting karena formula yang cocok dalam menganalisis data. Artikel ini menjelaskan dengan jelas mengenai 1). jenis- jenis variabel berdasarkan data- data yang dimiliki: a). Variabel diskrit, b). Variabel continyu. Variabel continyu terdiri dari data dominal dan bilangan bulat. Variabel continyu terdiri dari data ordinal, data interval, dan data rasio. 2). Skala pengukuran yang digunakan dalam dalam skala statistika yakni nominal, ordinal interval dan rasio. 3). Statistik Deskriptif terdiri dari pengertian Statistik Deskriptif, Ruang Lingkup Statistik Deskriptif, penyajian data Statistik Deskriptif, metode dasar dalam Statistik Deskriptif. 4). statistik Inferensial terdiri dari pengertian statistik Inferensial, ruang lingkup statistik Inferensial, metode statistik Inferensial yaitu statistik Parametrik, statistik non- Parametrik, Perbedaan Statistik Deskriptif dengan Statistik Inferensial. 5). Statistik Parametrik meliputi pengertia, ciri- ciri, keunggulan dan kelemahan. 6). Statistik non- Parametrik meliputi pengertia, ciri- ciri, keunggulan dan kelemahan
\end{abstract}

Kata Kunci: Jenis variabel, skala pengukuran, statistik deskriptif, statistic inferensial , statistik Parametrik, statistic non- parametrik. 


\section{PENDAHULUAN}

Statistik memegang peranan yang penting dalam penelitian. baik dalam penyusunan model, perumusan hipotesa. dalam pengembangan alat dan instrumen pengumpulan data,dalam penyusunan desain penelitjian, dalam penentuan sampel dan dalam analisa data. dalam banyak hal. pengolahan dan analisa data tidak luput dari penerapan teknik dan metode statistik tertentu yang mana kehadirannya dapat memberikan dasar bertolak dalam menjelaskan hubungan-hubungan yang terjadi. statistik dapat digunakan sebagai alat untuk mengetahui apakah hubungan Kausalitas antara dua atau lebih variabel benar-benar terkait secara benar dalam satu kualitas empiris ataukah hubungan tersebut hanya bersifat random atau kebetulan saja.

statistik telah memberikan teknik-teknik sederhana dalam mengklarifikasikan data serta dalam menyajikan data secara lebih mudah sehingga data tersebut dapat dimengerti secara lebih mudah. statistik telah dapat menyajikan suatu ukuran yang dapat mensifatkan populasi atau pun menyatakan variasinya dan memberikan gambaran yang lebih baik tentang kecenderungan tengah-tengah dari variabel.

statistik dapat menolong peneliti untuk menyimpulkan apakah suatu perbedaan yang diperoleh benar-benar berbeda secara signifikan Apakah pengumpulan yang diambil cukup representatif untuk memberikan inferensi terhadap populasi tertentu.

Teknik-teknik statistik juga dapat digunakan dalam pengujian hipotesis mengingat tujuan penelitian pada umumnya adalah untuk menguji hipotesa hipotesa yang telah dirumuskan, maka statistik telah banyak sekali menolong peneliti dalam mengambil keputusan untuk menerima atau menolak suatu hipotesa. statistik juga dapat meningkatkan kecermatan peneliti dalam rangka mengambil keputusan terhadap kesimpulan-kesimpulan yang ingin ditarik. 


\section{PEMBAHASAN}

\section{A. Jenis Variabel Dan Skala Pengukuran}

\section{Jenis variable}

1) Variable diskrit(discreet variable)

Variabel diskrit adalah variable yang berupa data pengkategorian atau membedakan atau mengelompokkan jenis tertentu. Data jenis ini disebut data nominal atau data dikotomik. misalnya: data dikotomik 1 untuk kategori benar dan 0 dan untuk kategori salah. data dikotomi ini seringkali digunakan mahasiswa untuk mengkategorikan jawaban benar dan salah dari testes jenis objek semisal pilihan ganda (Multiple Choicce Question (MCQ). Contoh lainnya adalah ah simbol 1 untuk pria dan 2 untuk wanita. angka 10 , atau 12 Hanya merupakan label untuk penanda kategori. Jadi bukan berarti bahwa angka 2 lebih tinggi nilainya dari 1 atau 0 . Data tersebut bersifat tetap ( Setara) dan tentu tidak dapat digunakan Kan dalam operasi hitung.

Selain itu, data yang termaksud dalam variabel diskrit (data distrit) adalah data bilangan bulat. bilangan bulat adalah bila bilang yang tidak dalam bentuk pecahan/ desimal. misalnya jumlah penjualan mobil tahun 2016 adalah 300 buah. data tersebut selalu bulat. jadi tidak ada ada 2,5 buah mobil. contoh lainnya adalah Jumlah manusia. tidak akan ada pernyataan " jumlah penduduk di jalan G .Obos XVI adalah 101,6 orang.

2) Variabel kontinyu (Continuous Variable)

Berbeda dengan variabel diskrit yang mana data hanya berfungsi sebagai tabel, maka variabel kontinyu merupakan data yang dapat digunakan untuk operasi hitung. data kontinu adalah data yang diperoleh dari hasil perhitungan atau pengurangan, sehingga data tidak hanya berupa bilangan bulat, tetapi juga bisa dalam bentuk desimal, misalnya 2,5.

data kontinu juga bisa dalam bentuk bilangan bulat, namun kelompok data tersebut memungkinkan variasinya ke dalam bentuk pecahan. contoh dari data untuk variabel ini ini adalah Jumlah benar atau salah dalam suatu tes skor nilai, ranking tinggi badan berat badan panjang jarak data tersebut dapat berubah-ubah atau bervariasi.

berikut ini jenis-jenis data dalam variabel kontinyu:

a) data ordinal

Data ordinal merupakan data peringkat. misalnya juara 1, juara 2 dan juara 3. angka tersebut mempunyai makna, lebih dari sekedar label seperti pada data nominal diatas. juara 1 tentu lebih pintar dari juara 2 dan seterusnya.

b) data interval (rintangan)

data interval merupakan data jenis rentangan yang sudah dapat digunakan kan dalam operasi hitung.Selain itu data, data interval mempunyai adanya jarak yang jelas diantara masing-masing data.

misalnya,MK 1 bernilai 1 SKS diberikan waktu 50 menit, MK II bernilai 2 SKS diberikan waktu 100 menit, dan dan MK III bernilai 3 SKS diberikan waktu 150 menit. disederhanakan 
menjadi 50- 100-150. maka terlihat bahwa masing-masing data mempunyai rentengan sebesar 50 .

contoh lainnya berapa kali anda pergi pulang ke kampung halaman dalam satu tahun? a.1 kali,b .2 kali, C. 3 kali,d.4 kali. angka-angka tersebut menggunakan interval 1.

c) data rasio

data rasio merupakan data pengukuran yang paling kompleks dan tentu dapat digunakan dalam operasi hitung angka dalam data rasio merupakan angka yang sesungguhnya, bukan hanya sebagai simbol. apabila Ada angka 0 berarti memang angka 0 yang sebenarnya atau mutlak. contoh dari data ini adalah data hasil pengukuran/ perhitungan massa, panjang dan waktu.

misalnya, data berat badan, berat badan a mempunyai berat $45 \mathrm{~kg}$, B mempunyai berat 90 kg. Jika dilihat menggunakan skala rasio berat badan a adalah setengah dari berat badan B.

\section{2. skala pengukuran}

a) skala nominal

skala nominal merupakan Skala yang paling lemah/ rendah di antara skala pengukuran yang ada. skala nominal hanya bisa membedakan benda atau peristiwa yang satu dengan yang lainnya berdasarkan nama (predikat). skala pengukuran nominal digunakan untuk mengklasifikasi Objek, Individual atau kelompok dalam bentuk kategori.

pemberian angka atau simbol pada skala nomial tidak memiliki maksud kuantitatif hanya menunjukkan ada atau tidak adanya atribut atau karakteristik pada objek yang diukur. misalnya, jenis kelamin diberi kode 1 untuk laki-laki dan kode 2 untuk perempuan. angka ini hanya berfungsi sebagai label kategori, tanpa memiliki nilai intrinsik dan tidak memiliki arti apapun. kita tidak bisa mengatakan perempuan dua kali dari laki-laki. kita bisa saja mengkode laki-laki Menjadi 2 dan perempuan dengan kode 1, atau bilangan apapun Asal kodenya berbeda antara laki-laki dan perempuan.

Karena tidak memiliki nilai instrinsik, maka angka-angka (kode-kode) Yang kita berikan tersebut tidak memiliki sifat sebagaimana bilangan pada umumnya. oleh karenanya, pada variabel dengan skala nominal tidak dapat diterapkan operasi matematika standar( aritmatik) pengurangan, penjumlahan, perkalian, dan sebagainya. peralatan statistik yang sesuai dengan skala nominal adalah peralatan statistik yang berbasiskan( berdasarkan) jumlah dan proporsi seperti modus, distribusi frekuensi,chi Square dan beberapa peralatan statistik non- parametrik lainnya.

b) Skala ordinal

Kalau ordinal ini lebih tinggi daripada skala nominal, dan sering juga disebut dengan skala peringkat. Hal ini karena dalam skala ordinal, lambang-lambang bilangan hasil pengukuran selain menunjukkan perbedaan juga menunjukkan Urutan atau tingkatan objek yang diukur menurut karakteristik tertentu. 
misalnya tingkat kepuasan seseorang terhadap produk. bisa kita beri angka dengan $5=$ sangat puas, $4=$ puas, $3=$ Kurang puas, $2=$ tidak puas dan $1=$ sangat tidak puas.

dalam skala ordinal, tidak seperti skala nominal, ketika kita ingin mengganti angka-angkanya, harus dilakukan secara berurut dari besar ke kecil atau dari kecil ke besar. jadi, tidak boleh kita buat $1=$ sangat puas, $2=$ tidak puas, $3=$ puas dstnya. Yang boleh adalah $1=$ Sangat puas, $2=$ puas, $3=$ kurang puas dstnya.

selain itu, angka perlu diperhatikan dari kata karakteristik skala ordinal adalah ah meskipun nilainya sudah memiliki batas yang jelas tetapi belum memiliki jarak( selisih). kita tidak tahu berapa jarak kepuasan dari tidak puas ke kurang puas. dengan kata lain juga, walaupun sangat puas kita beri angka 5 dan dan sangat tidak buat kita beri angka 1 ,kita tidak bisa mengatakan bahwa kepuasan yang sangat puas lima kali lebih tinggi Dibanding kan yang sangat tidak puas.

sebagaimana halnya pada skala nominal, pada skala ordinal kita juga tidak dapat menerapkan operasi matematika standar seperti pengurangan, penjumlahan, perkalian dan lainnya peralatan statistik yang sesuai dengan skala ordinal juga adalah peralatan statistik yang berbasiskan jumlah dan proporsi seperti modus, distribusi frekuensi Chi Square dan beberapa peralatan statistik non- parametrik lainnya.

c) Skala interval

Skala interval mempunyai karakteristik seperti yang dimiliki oleh skala nominal dan ordinal dengan ditambah karakteristik lain,yaitu berupa adanya interval yang tetap. dengan demikian skala interval sudah memiliki nilai intrinsik, sudah memiliki jarak, tetapi jarak tersebut belum merupakan kelipatan. pengertian "Jarak belum merupakan kelipatan" ini kadang-kadang diartikan bahwa skala interval tidak memiliki nilai nol mutlak. Skala interval ini sudah benar-benar angka dan dan kita sudah dapat menerapkan semua operasi matematika serta peralatan statistik kecuali yang berdasarkan pada rasio seperti koefisien variasi.

d) Skala rasio

Skala rasio adalah skala data dengan kualitas paling tinggi. pada skala rasio, terdapat semua karakteristik skala nominal, ordinal dan skala interval ditambah dengan sifat adanya nilai nol yang bersifat Mutlak. nilai nol mutlak Wini artinya adalah nilai dasar yang tidak bisa diubah meskipun menggunakan skala yang lain. oleh karenanya, pada skala rasio, pengukuran sudah mempunyai nilai perbandingan/ rasio.

pengukuran pengukuran dalam skala rasio yang sering digunakan adalah pengukuran tinggi dan berat. misalnya berat benda A adalah $30 \mathrm{~kg}$, sedangkan benda B adalah $60 \mathrm{~kg}$. maka dapat dikatakan bahwa benda $\mathrm{B}$ dua kali lebih berat dibandingkan benda $\mathrm{A}$. 


\section{B. Perbedaan statistik deskriptif dan inferensial}

\section{Statistik Deskriptif}

a) Pengertian Statistik Deskriptif

Statistik deskriptif merupakan proses transformasi data penelitian dalam bentuk tabulasi sehingga mudah dipahami dan di interpretasikan. Informasi yang di dapatkan yang berasal dari statistik deskriptif ini antara lain ukuran pemusatan data, ukuran penyebaran data, dan juga kecenderungan suatu gugus data.

b) Ruang Lingkup Statistik Deskriptif

Ruang lingkup statistik deskriptif antara lain yaitu penyajian data, pengukuran tendensi sentral, pengukuran variabilitas. Angka indeks, dan deret berkala.

\section{c) Penyajian Data Statistik Deskriptif}

Penyajian data terdiri dari dua yaitu dalam bentuk grafis dan dalam bentuk numerik. Penyajian data secara grafis, antara lain Histogram, Pie Chart, Poligon, Ogive, dan Stem and Leaf. Sedangkan penyajian data secara numerik, antara lain Central Tredency, Dispersion atau pencaran, Fractile, Skewness, dan Pengukuran Keruncingan.

d) Metode Dasar dalam Statistik Deskriptif

Ada dua macam metode dasar di dalam statistik deskriptif, antara lain numerik dengan menghitung nilai statistik dari sekumpulan data dan grafis dengan mengidentifikasi pola-pola tertentu dalam data.

Terdapat tiga karakteristik atau ciri utama dari variabel tunggal, diantaranya yaitu:

a. Distribusi data (distribusi frekuensi) diartikan sebagai daftar sebaran data yang diikuti dengan nilai frekuensinya. Data kemudian dikelompokkan ke dalam beberapa kelas sehingga karakteristik atau ciri penting data tersebut bisa dengan cepat terlihat.

b. Ukuran pemusatan atau tendensi sentral (Central Tendency), Pada pengukuran aritmatika yang diarahkan dalam menunjukan suatu nilai yang mewakili nilai pusat ataupun nilai sentral dari suatu gugus data dikenal dengan sebutan ukuran tendensi sentral. Adapun tiga jenis ukuran tendensi sentral yaitu Mean, Median, dan Modus.

c. Ukuran penyebaran (Dispersion), Salah satu hal penting yang ada yaitu suatu variabel ialah bentuk distribusinya, yang menggambarkan frekuensi dari berbagai selang nilai variabel.

\section{Statistik Inferensial}

a. Pengertian

Statistik inferensial adalah metode yang digunakan untuk mengetahui populasi berdasarakan sampel dengan menganalisis dan menginterpretasikan data menjadi sebuah kesimpulan (Hatani, 2008). Statistik inferensial ini juga merupakan suatu rangkuman dari semua metode atau cara yang berkaitan dengan analisis sebagian data, yang mana selanjutnya akan sampai pada peramalan ataupun penarikan kesimpulan tentang keseluruhan data induk dari populasi tersebut. Sifat statistik inferensial yaitu (1) data yang dianalisis berasal dari random sampling; (2) menggeneralisasikan dan meramalkan baik tentang ciri penting suatu 
variabel maupun hubungan antar variabel; (3) generalisasi dan ramalan yang dibuat diberlakukan bagi keseleruhan populasi atas dasar hasil analisis data dari sampel; dan (4) generalisasi dan ramalan dilaksanakan dengan uji hipotesis atau pengecekan asumsi.

b. Ruang Lingkup Statistik Inferensial

Ruang lingkup statistik infernsial yaitu probabilitas, metode sampel, pengujian hipotesis, statistik parametrik (korelasi dan regresi), dan statistik nonparametrik.

c. Metode Statistik Inferensial

1) Statistik Parametrik

Statistik parametrik berguna untuk menarik kesimpula atas beberapa gejala yang dapat disimpulkan ke keseluruhan bobotnya paling tinggi (populasi). Statistik parametrik menggunakan asumsi mengenai populasi dan membutuhkan pengukuran kuantitatif dengan level data interval atau rasio.

2) Statistik Nonparametrik

Statistik nonparametrik dari indicator beberapa gejala yang hanya berlaku kesimpulan saja pada bebebrapa bagian dari suatu keseluruhan. Statistik nonparametrik menggunakan lebih sedikit asumsi mengenai populasi dan membutuhkan data dengan level serendah-rendahnya ordinal.

\section{Perbedaan Statistik Deskriptif dengan Statistik Inferensial}

Statistik deskriptif hanya terbatas dalam penyajian data pada bentuk tabel, diagram, ataupun grafik serta besaran lainnya. Statistik deskriptif bertujuan untuk mendeskripsikan karakteristik data. Sementara statistik inferensial tidak hanya mencakup statistik deskriptif saja, tetapi juga dapat dipakai dalam melakukan estimasi serta penarikan kesimpulan kepada populasi dari sampelnya. Statistik inferensial bertujuan untuk mengambil kesimpulan untuk populasi dengan menganalisis sampel.

\section{Statistik Parametrik dan nonparametric}

\section{Statistik Parametrik}

Statistik Parametrik yaitu ilmu statistik yang mempertimbangkan jenis sebaran atau distribusi data, yaitu apakah data menyebar secara normal atau tidak. Dengan kata lain, data yang akan dianalisis menggunakan statistik parametrik harus memenuhi asumsi normalitas. Pada umumnya, jika data tidak menyebar normal, maka data seharusnya dikerjakan dengan metode statistik non-parametrik, atau setidak-tidaknya dilakukan transformasi terlebih dahulu agar data mengikuti sebaran normal, sehingga bisa dikerjakan dengan statistik parametrik.

Contoh metode statistik parametrik :
a. Uji-z (1 atau 2 sampel)
b. Uji-t (1 atau 2 sampel)
c. Korelasi pearson,
d. Perancangan percobaan (one or two-way anova parametrik), dll. 
Ciri-ciri statistik parametrik :

- Data dengan skala interval dan rasio

- Data menyebar/berdistribusi normal

Keunggulan dan kelemahan statistik parametrik

Keunggulan :

1.Syarat syarat parameter dari suatu populasi yang menjadi sampel biasanya tidak diuji dan dianggap memenuhi syarat, pengukuran terhadap data dilakukan dengan kuat.

2. Observasi bebas satu sama lain dan ditarik dari populasi yang berdistribusi normal serta memiliki varian yang homogen.

Kelemahan :

1. Populasi harus memiliki varian yang sama.

2. Variabel-variabel yang diteliti harus dapat diukur setidaknya dalam skala interval.

3. Dalam analisis varian ditambahkan persyaratan rata-rata dari populasi harus normal dan bervarian sama, dan harus merupakan kombinasi linear dari efek-efek yang ditimbulkan.

\section{Statistika Non Parametrik}

Statistik Non-Parametrik, yaitu statistik bebas sebaran (tidak mensyaratkan bentuk sebaran parameter populasi, baik normal atau tidak). Selain itu, statistik non-parametrik biasanya menggunakan skala pengukuran sosial, yakni nominal dan ordinal yang umumnya tidak berdistribusi normal.

Contoh metode statistik non-parametrik :

a. Uji tanda (sign test)

b. Rank sum test (wilcoxon)

c. Rank correlation test (spearman)

d. Fisher probability exact test.

e. Chi-square test, dll

Ciri-ciri statistik non-parametrik :

- Data tidak berdistribusi normal

- Umumnya data berskala nominal dan ordinal

- Umumnya dilakukan pada penelitian sosial

- Umumnya jumlah sampel kecil.

Keunggulan dan kelemahan statistik non-parametrik :

Keunggulan : 
1. Tidak membutuhkan asumsi normalitas.

2. Secara umum metode statistik non-parametrik lebih mudah dikerjakan dan lebih mudah dimengerti jika dibandingkan dengan statistik parametrik karena ststistika non-parametrik tidak membutuhkan perhitungan matematik yang rumit seperti halnya statistik parametrik.

3. Statistik non-parametrik dapat digantikan data numerik (nominal) dengan jenjang (ordinal).

4. Kadang-kadang pada statistik non-parametrik tidak dibutuhkan urutan atau jenjang secara formal karena sering dijumpai hasil pengamatan yang dinyatakan dalam data kualitatif.

5. Pengujian hipotesis pada statistik non-parametrik dilakukan secara langsung pada pengamatan yang nyata.

6. Walaupun pada statistik non-parametrik tidak terikat pada distribusi normal populasi, tetapi dapat digunakan pada populasi berdistribusi normal.

Kelemahan :

1. Statistik non-parametrik terkadang mengabaikan beberapa informasi tertentu.

2. Hasil pengujian hipotesis dengan statistik non-parametrik tidak setajam statistik parametrik.

3. Hasil statistik non-parametrik tidak dapat diekstrapolasikan ke populasi studi seperti pada statistik parametrik. Hal ini dikarenakan statistik non-parametrik mendekati eksperimen dengan sampel kecil dan umumnya membandingkan dua kelompok tertentu 


\section{KESIMPULAN}

1. Jenis variabel terbagi menjadi 2:

a) Variable diskrit (discreet Variable) Variabel diskrit adalah variable yang berupa data pengkategorian atau membedakan atau mengelompokkan jenis tertentu.

b) Variabel kontinyu variabel kontinyu merupakan data yang dapat digunakan untuk operasi hitung. Jenis- jenis data variabel kontinyu: data ordinal, data interval, data rasio.

2. Skala pengukuran yaitu:

a) Skala nominal skala nominal merupakan Skala yang paling lemah/ rendah di antara skala pengukuran yang ada.

b) Skala ordinal sering juga disebut dengan skala peringkat. Hal ini karena dalam skala ordinal, lambang-lambang bilangan hasil pengukuran selain menunjukkan perbedaan juga menunjukkan Urutan atau tingkatan objek yang diukur menurut karakteristik tertentu.

c) Skala interval Skala interval mempunyai karakteristik seperti yang dimiliki oleh skala nominal dan ordinal dengan ditambah karakteristik lain,yaitu berupa adanya interval yang tetap. dengan demikian skala interval sudah memiliki nilai intrinsik, sudah memiliki jarak, tetapi jarak tersebut belum merupakan kelipatan.

d) Skala rasio Skala rasio adalah skala data dengan kualitas paling tinggi. pada skala rasio, terdapat semua karakteristik skala nominal, ordinal dan skala interval ditambah dengan sifat adanya nilai nol yang bersifat Mutlak.

3. Statistik deskriptif bertujuan untuk mendeskripsikan karakteristik data. Sedangkan statistik inferensia bertujuan untuk mengambil kesimpulan untuk populasi dengan menganalisis sampel.

Statistik deskriptif biasanya hanya disajikan dalam bentuk tabel dan grafik. Statistik uji yang digunakan pun terbilang sederhana seperti rata-rata, varians, dll. Sedangkan statistik inferensial, statistik yang digunakan sudah tergolong sangat rumit. Tidak semua orang mampu menggunakan statistik inferensial sehingga dibutuhkan keseriusan dan pembelajaran khusus sebelum menggunakannya.

4. Statistik Parametrik dan nonparametrik

Statistic parametrik:

a) Memerlukan asumsi distribusi dari data yang digunakan. Biasanya distribusi data yang diperlukan adalah distribusi normal.

b) Memerlukan jenis data bersifat metrik (kuantitatif). Bisa dikatakan juga bahwa data yang digunakan hanya data dalam bentuk data interval atau rasio.

c) Biasanya jumlah data yang digunakan lebih atau sama dengan 30 (data berukuran besar), sebab data yang lebih atau sama dengan 30 diasumsikan mengikuti teorema limit pusat (central limit teorema).

Statistic nonparametrik:

a) Tidak memerlukan asumsi distribusi sehingga sebaran data bebas.

b) Memerlukan data metrik (kuantitaif) dan nonmetrik (kualitatif). Atau bisa dikatakan bahwa data yang digunakan bisa dalam bentuk data nominal, ordinal, interval atau rasio.

c) Biasanya jumlah data yang digunakan kurang dari 30 . 


\section{DAFTAR ISI}

Arsyam, M. (2020). Manajemen Pendidikan Islam.

Herianto, H. (2020). Tehnik Menulis Artikel Konseptual.

Herianto, H. (2020). Telah kurikulum 2013: Hasil Revisi Tahun 2018.

Jusmiana, A, \& herianto, H. (2020) Suplemen Materi Statistic Terapan Dalam Ilmu Kesehatan.

Sapada, A. O. \& Arsyam, M. (2020). Ilmu Pengetahuan Dan Teknologi Menurut Pandangan Islam.

Sarwono, Jonathan. (2006). Metode Penelitian Kuantitative \& Kualitatif. Yogyakarta:Graha Ilmu.

Amri A, Junaidi, Yulmadi. (2009). Metodologi penelitian ekonomi dan penerapannya. Bogor. IPB Press.

Nurgiantoro, B, Gunawan, Marzuki. (2000). Statistik terapan untuk penelitian ilmu-ilmu social. Yogyakarta: Gadjah Mada University Press.

http://societykamaru.blogspot.com/2014/01/makalah-statistik-parametrik-dan-non.html 